\title{
Methanol pigment extracts derived from two marine actinomycetes exhibit antibacterial and antioxidant activities
}

\author{
DOVA KELVIN MESRIAN ${ }^{1}$, WIDYA ESTI PURWANINGTYAS ${ }^{1}$, RIKA INDRI ASTUTI ${ }^{1}$, \\ AKHMAD ENDANG ZAINAL HASAN ${ }^{2}$, ARIS TRI WAHYUDI ${ }^{1, \vee}$ \\ ${ }^{1}$ Department of Biology, Faculty of Mathematics and Natural Sciences, Institut Pertanian Bogor. J1. Agatis, Bogor, 16680, West Java, Indonesia, \\ Tel./fax.: +62-251-8622833, `email: ariswa@apps.ipb.ac.id. \\ ${ }^{2}$ Department of Biochemistry, Faculty of Mathematics and Natural Sciences, Institut Pertanian Bogor. J1. Tanjung, Bogor, 16680, West Java, Indonesia
}

Manuscript received: 4 September 2021. Revision accepted: 25 September 2021.

\begin{abstract}
Mesrian DK, Purwaningtyas WE, Astuti RI, Hasan AEZ, Wahyudi AT. 2021. Methanol pigment extracts derived from two marine actinomycetes exhibit antibacterial and antioxidant activities. Biodiversitas 22: 4440-4447. In recent years, natural pigments produced by marine microorganisms, especially actinomycetes, have become an important source of medically valuable drugs and other active compounds. Based on that crucial fact, this study aimed to determine the toxicity, antimicrobial, and antioxidant activities of methanolic pigment extract derived from marine actinomycetes HV11.P3 and SCA54.P2. Both extracts exhibited high toxicity activity based on Brine Shrimp Lethality Test (BSLT). The results showed the lethal concentration 50\% (LC50) values of actinomycetes HV11.P3 and SCA54.P2 pigment crude extracts were $94.60 \mu \mathrm{g} / \mathrm{mL}$ and $131.22 \mathrm{mg} / \mathrm{mL}$, respectively. The antimicrobial activity of those extracts was also tested against several microbes and showed the best results for inhibiting against Bacillus subtilis and Escherichia coli. Furthermore, we assessed the antioxidant activity using 2,2-diphenyl-1-picrylhydrazyl (DPPH) radicals and the results showed the inhibitory concentration 50\% ( $\mathrm{IC}_{50}$ ) values of actinomycetes HV11.P3 and SCA54.P2 pigment crude extracts were $231.08 \mu \mathrm{g} / \mathrm{mL}$ and $369.3 \mu \mathrm{g} / \mathrm{mL}$, respectively. By using GC-MS analysis, we identified chemical compounds of actinomycete pigment crude extracts, revealing that the most dominant compounds were 1H-Purine-2,6-dione, 3,7-dihydro-1,3,7-trimethyl- (CAS) (44.65\%) for HV11.P3 and 5-Methoxypyrrolidin-2-one (30.23\%) for SCA54.P2. The 16S rRNA gene sequence analysis showed that actinomycete HV11.P3 and actinomycete SCA54.P2 had the closest similarity to Micromonospora chalcea strain 1464-217L and Micromonospora tulbaghiae strain TVU1, respectively. This study revealed that two pigment crude extracts derived from actinimycetes HV11.P3 and SVA54.P2 had antibacterial, antioxidant, and toxicity activities. The actinomycete SCA54.P2 pigment crude extract had the best activity as an antibacterial against E. coli ATCC 8739, while actnomycete HV11.P3 pigment crude extract had the best activity as an antioxidant.
\end{abstract}

Keywords: Actinomycetes, antimicrobial, antioxidant, pigment, toxicity

\section{INTRODUCTION}

In recent years, various problems in the health sector have emerged and attracted the attention of the world. These include resistance to several types of pathogens microbial and increased deaths due to infection with degenerative diseases (Prestinaci et al. 2015; Kharirie and Andriani 2020). Resistance occurs when bacteria, viruses, fungi, and parasites change continuously and reduce the effectiveness of the commonly used antimicrobial agent (Founou et al. 2017). Furthermore, infections that are difficult to treat will increase the risk of disease spread, disease severity, and mortality which have a long-term impact (Roope et al. 2019). Chronic bacterial, viral, and fungal infections might be causative factors for inflammatory and worsen degenerative diseases. Therefore, the discovery of new antimicrobial compounds should be considered in the present and the future.

Degenerative diseases as a result of cell damage due to the aging process or various other factors that affect the number of free radicals in the body (Sahardi and Makpol 2019). The accumulation of free radicals will initiate multiple diseases such as Alzheimer's, Parkinson's, atherosclerosis, cardiovascular disorders, hypertension, and diabetes mellitus type 2 (Stambler 2017). Naturally, the human body can reduce free radicals in a certain amount by antioxidant compounds that have been formed in the body. However, if oxidative stress occurs, which is an imbalance between the number of free radicals and the number of antioxidants in the body, the body needs an external source of antioxidants to prevent the oxidation of the essential constituents of cells (Al-Snafi 2017). The other bioactive compound that can act as a tool against degenerative disease is the toxic compound. It has been proven that the toxic compound tested with the brine shrimp lethality test (BSLT) has a good correlation with cytotoxic activity in some solid human tumors (Mclaughlin et al. 1998).

Actinomycetes are Gram-positive, filamentous aerobic bacteria with high $\mathrm{G}+\mathrm{C}$ composition (Gong et al. 2018; Bhakyashree and Kannabiran 2018). Actinomycetes isolated from terrestrial were extensively researched, leading to the rediscovery of natural products that have been reported. On the other hand, marine actinomycetes are primarily a new resource of secondary metabolites including terpenes, peptides, sterols, fatty acids, alkaloids, amino acids and their derivatives (Liao et al. 2016; Pudi et al. 2016). The marine environment is capable of producing all of these compounds due to the enormous biodiversity 
and diverse environmental conditions (Bibi et al. 2020). Actinomycetes associated with marine sponges such as Micromonospora sp, have recently been used to produce many bioactive compounds with novel molecular scaffolds and significant pharmacological activities (Hifnawy et al. 2020). Thus, the genus Micromonospora is one of the prolific producer of secondary metabolites, especially as bioactive compounds.

The genus Micromonospora is a member of the Micromonosporaceae which includes 32 genera. This genus is found in various geographic environments such as soils, mangrove sediments, plants, marine habitats, and extreme environments (Trujillo et al. 2015; Hifnawy et al. 2020). More than 740 strains of Micromonospora have been identified to produce various bioactive compounds, one of the bioactive compound comes from the pigment (Berdy 2005). Micromonospora colonies have carotenoid pigments including yellow, orange, red, purple, brown, or black (Sineva et al. 2021). Some Micromonospora species with their soluble pigments are $M$. chalcea (yellow), $M$. halophytica (red-brown), M. olivasterospora (olive-green), M. purpureochromogenes (dark-brown), and $M$. rosaria (wine-red) (Genilloud 2015). In the previous study, we have isolated two pigmented actinomycetes from marine sponges, namely actinomycetes HV11.P3 and SCA54.P2 (unpublished data). To determine the potency of pigment crude extract, this study aimed to test the antimicrobial, antioxidant, and toxicity abilities of the pigment methanol extracts produced by the marine actinomycetes HV11.P3 and SCA54.P2.

\section{MATERIALS AND METHODS}

\section{Material}

Two pigmented marine actinomycetes, namely actinomycete HV11.P3 (greenish-black) and actinomycete SCA54.P2 (orange) used in this study had been isolated from sponges collected from Pramuka Island, Kepulauan Seribu, Indonesia (544’46.3 S $106^{\circ} 36^{\prime} 35.7$ E). Five microbes were used for the antimicrobial test, namely Bacillus subtilis ATCC 19659, Escherichia coli ATCC 8739, Pseudomonas aeruginosa ATCC 15442, Staphylococcus aureus ATCC 6538, and Candida albicans ATCC 10231, which were obtained from IPB Culture Collection, IPB University (Bogor, Indonesia).

\section{Procedures}

\section{Pigment extraction}

The extraction of pigments refers to method described by Dawoud et al. (2020) with slight modifications. Each of Actinomycete was cultured in $1 \mathrm{~L}$ of ISP-4 broth medium (10 g Soluble Starch, 1 g $\mathrm{MgSO}_{4} .7 \mathrm{H}_{2} \mathrm{O}, 1 \mathrm{~g} \mathrm{NaCl}, 1 \mathrm{~g}$ $\mathrm{K}_{2} \mathrm{HPO}_{4}, 2 \mathrm{~g}\left(\mathrm{NH}_{4}\right)_{2} \mathrm{SO}_{4}, 2 \mathrm{~g} \mathrm{CaCO}_{3}, 0.001 \mathrm{~g} \mathrm{FeSO}_{4} .7 \mathrm{H}_{2} \mathrm{O}$, $0.001 \mathrm{~g} \mathrm{MnCl}_{2} .4 \mathrm{H}_{2} \mathrm{O}$, and $\left.0.001 \mathrm{~g} \mathrm{ZnSO}_{4} .7 \mathrm{H}_{2} \mathrm{O}\right)$ and agitated continuously in orbital shaker at $100 \mathrm{rpm}$ for 14 days at room temperatur. The actinomycetes cultures were then centrifuged at $6000 \mathrm{rpm}$ for 15 minutes. The cell biomass were then added with $1 \mathrm{~L}$ of methanol as a solvent and then heated at $50^{\circ} \mathrm{C}$ for 15 minutes in water bath until the cell became colorless. After that, the methanol phase was separated with the cell biomass by centrifugation at $6000 \mathrm{rpm}$ for 15 minutes. The methanol solvent was evaporated using a rotary evaporator at $50^{\circ} \mathrm{C}$. The crude extracts were collected and dissolved in $10 \%$ dimethyl sulfoxide (DMSO), and then stored at $4^{\circ} \mathrm{C}$ for further assay.

\section{Toxicity test}

The toxicity test was performed using Brine Shrimp Lethality Test (BSLT) according to Meyer et al. (1982). Twenty Artemia salina larvae were placed in each vial containing $4 \mathrm{~mL}$ of seawater and pigment crude extracts in $0,10,100,250,500,750$, and $1000 \mu \mathrm{g} / \mathrm{mL}$. The vials containing larvae and pigment extracts were incubated under a light condition for 24 hours at room temperature. The dead larvae were counted, and the percentage of mortality was calculated using the following formula:

$\%$ Mortality $=\left(\frac{\sum \text { Sample larvae mortality }-\sum \text { Control larvae mortality }}{\sum \text { Total larvae }}\right) \times 100$

A linear regression model and probit analysis were used to determine the $\mathrm{LC}_{50}$ value of each extract.

\section{Antimicrobial test}

The antimicrobial activity was performed using the disc diffusion method. The pigment extracts were tested against several clinical isolates. B. subtilis ATCC 19659, E. coli ATCC 8739, P. aeruginosa ATCC 15442, and S. aureus ATCC 6538 were inoculated into a Mueller-Hinton Agar medium, meanwhile $C$. albicans ATCC 10231 was inoculated into a Potato Dextrose Agar medium. A paper disc $(6 \mathrm{~mm})$ containing various concentrations of the extracts $(250,500,750$, and $1000 \mu \mathrm{g} / \mathrm{mL})$ was placed on the surface of agar plate medium. Tetracycline (100 $\mu \mathrm{g} / \mathrm{mL}$ ) was used as a positive control and $10 \%$ dimethyl sulfoxide (DMSO) was used as a negative control. The plates were incubated for 24 hours at room temperature, and the diameter of inhibition zones formed was measured.

\section{Antioxidant test}

The antioxidant activity of the pigment extracts was determined using DPPH radical according to Batubara et al. (2009) with modification. Five hundred microliters of each extract at various concentrations $(0,7.81,15.63$, $31.25,62.5,125,250$, and $500 \mu \mathrm{g} / \mathrm{mL}$ ) were mixed with $500 \mu \mathrm{L}$ of 2,2-diphenyl-1-picrylhydrazyl (DPPH) reagent $(0.125 \mu \mathrm{M}$ in methanol). The mixture was incubated at room temperature for 30 minutes in the dark condition, then the absorbance of the sample was measured using a spectrophotometer at $514 \mathrm{~nm}$ (Thermo spectronic-Genesis 20, Thermo Fisher Scientific, USA). Ascorbic acid was used as a positive control. The percentage of inhibition was calculated using the following formula:

$$
\% \text { Inhibition }=\left[1-\left(\frac{\text { Sample absorbance-Control absorbance }}{\text { Blanko absorbance }- \text { Control absorbance }}\right)\right] \times 100
$$

A linear regression model was used to determine the $\mathrm{IC}_{50}$ value of each extract. 


\section{Chemical compound analysis}

The pigment extract of the isolate HV11.P3 and SCA54.P2 was analyzed using Gas Chromatography in Agilent 5977B GC/MSD (Agilent Technologies, USA). 0.6 $\mu \mathrm{L}$ of extract solution diluted in methanol was injected into a column with HP-5MS column type $(30 \mathrm{~m} \times 250 \mu \mathrm{m} \times$ $0.25 \mu \mathrm{m})$. The initial oven temperature was $80^{\circ} \mathrm{C}$ and gradually increased at $15^{\circ} \mathrm{C} / \mathrm{min}$ until $300^{\circ} \mathrm{C}$ and held for 20 minutes. Helium gas was used as a carrier at a $1 \mathrm{~mL} / \mathrm{min}$ flow rate. The injection temperature was $300^{\circ} \mathrm{C}$ and the aux temperature was maintained at $300^{\circ} \mathrm{C}$. The result was analyzed by the GC-MS Pyrolysis program (WILLEY9THN 08. L).

\section{Molecular identification}

The genomic DNA of Actinomycete HV11.P3 and SCA54.P2 were extracted using Presto $^{\mathrm{TM}}$ Mini gDNA Bacteria Kit (Geneaid, Taiwan) following the protocol's guidelines. The $16 \mathrm{~S}$ rRNA gene $(1480 \mathrm{bp})$ were amplified using primers 20F (5'- CAGGCCTAACACATGCA AGTC-3') dan 1500R (5'-GGGCGGWGTGTACAAGGC3') (Weisberg et al. 1991). The PCR was performed using $\mathrm{MyTaq}^{\mathrm{TM}} \mathrm{HS}$ Red Mix (Bioline, United Kingdom). The PCR conditions were pre-denaturation at $95^{\circ} \mathrm{C}$ for $2 \mathrm{~min}$, denaturation at $95^{\circ} \mathrm{C}$ for $30 \mathrm{sec}$, annealing at $55^{\circ} \mathrm{C}$ for 30 sec, extension at $72^{\circ} \mathrm{C}$ for $1 \mathrm{~min}$, and post extension at $95^{\circ} \mathrm{C}$ for $7 \mathrm{~min}$. PCR products were visualized using $1 \%$ (w/v) gel agarose electrophoresis and the DNAs were sequenced in First BASE (Selangor, Malaysia). The sequences were aligned to National Centre or Biotechnology Information (NCBI) database using
Nucleotide Blast (https://blast.ncbi.nlm.nih.gov/), and the phylogenetic tree was constructed using Molecular Evolutionary Genetic Analysis X (MEGA X) neighbor joining p-distance model with 1000 bootstrap replication.

\section{RESULTS AND DISCUSSION}

\section{The pigment extraction}

The Actinomycete HV11.P3 and SCA54.P2 showed greenish-black and orange colonies on ISP-4 agar medium at seven days of incubation at room temperature. The HV11.P3 and SCA54.P2 were cultured in ISP-4 broth medium and incubated for 14 days on a rotary shaker prior to the pigment extraction. The pigment crude extracts showed greenish-black for HV11.P3 and brownish-orange for SCA54.P2 (Figure 1). The pigment extract yield of both actinomycete HV11.P3 and SCA54.P2 were $0.23 \%$ and $0.18 \%$, respectively (Table 1 ).

\section{Toxicity of pigment extracts}

Based on the BSLT test, both of the pigment extracts of actinomycete HV11.P3 and SCA54.P2 showed toxicity activity against Artemia salina. The toxicity was expressed as $\mathrm{LC}_{50}$ value. $\mathrm{LC}_{50}$ value is a standard for the lowest concentration that can kill $50 \%$ of test organisms ( $A$. salina). The lower of $\mathrm{LC}_{50}$ value indicated the better of toxicity. The $\mathrm{LC}_{50}$ of actinomycete HV11.P3 and SCA54.P2 pigment extracts were $94.53 \mu \mathrm{g} / \mathrm{mL}$ and 131.22 $\mu \mathrm{g} / \mathrm{mL}$, respectively (Table 2 ).
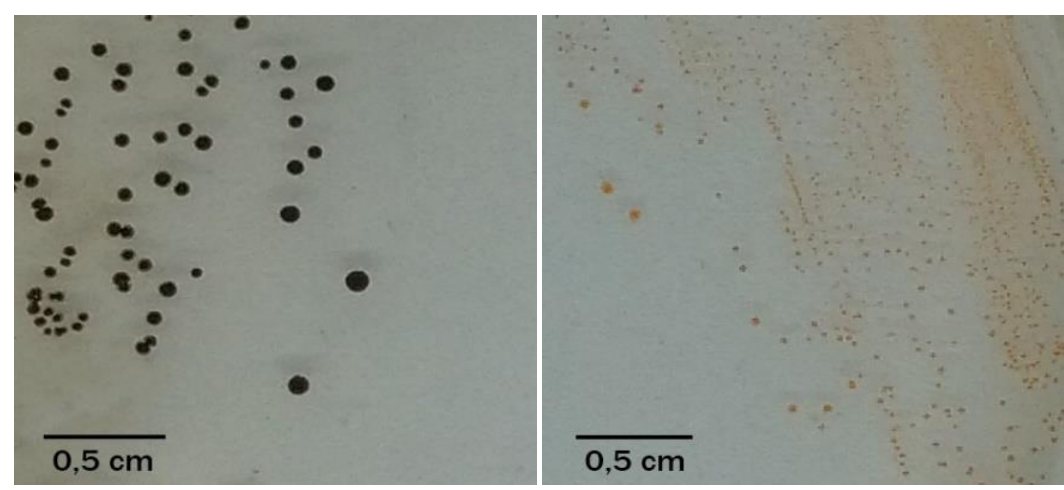

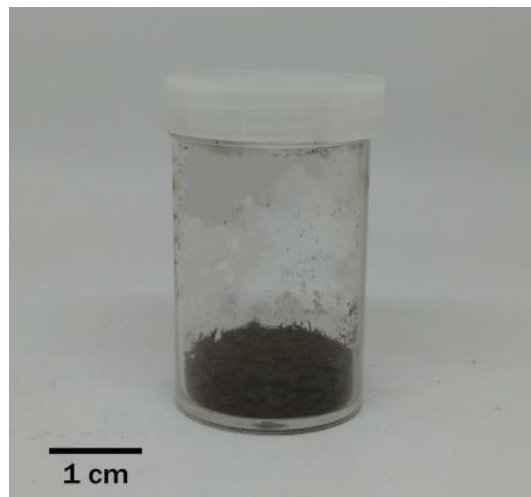

A

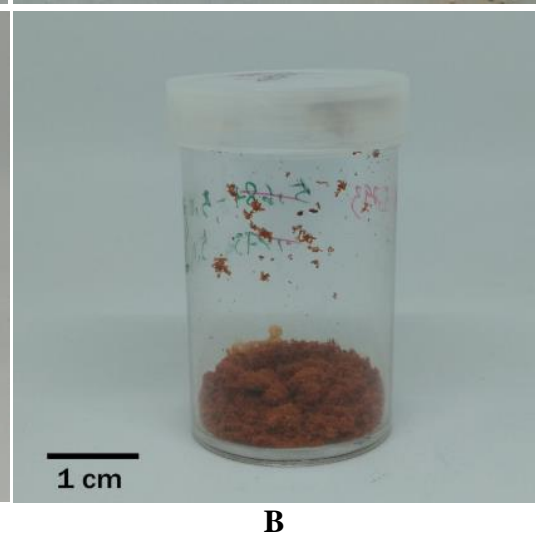

Figure 1. The colonies appearance of actinomycetes on ISP-4 agar medium at 7 days of incubation at room temperature and the pigment crude extract yielded after 14 days of culturing in ISP-4 broth medium: A. Actinomycete HV11.P3; B. Actinomycete SCA54.P2 
Table 1. The pigment extract yield derived from Actinomycete HV11.P3 and SCA54.P2.

\begin{tabular}{lccc}
\hline Pigment Extract & Culture Volume (L) & Weight (g) & Yield (\%) \\
\hline Actinomycete HV11.P3 & 1 & 2.33 & 0.23 \\
Actinomycete SCA54.P2 & 1 & 1.82 & 0.18 \\
\hline
\end{tabular}

Table 2. The toxicity of actinomycete HV11.P3 and SCA54.P2 pigment extracts based on Brine Shrimp Lethality Test

\begin{tabular}{lcccc}
\hline \multirow{2}{*}{ Pigment extract } & \multicolumn{4}{c}{ LC $_{\mathbf{5 0}}$ value $(\boldsymbol{\mu g} / \mathbf{~ m L})$} \\
\cline { 2 - 5 } & Replication 1 & Replication 2 & Replication 3 & Average \\
\hline Actinomycete HV11.P3 & 88.13 & 80.04 & 115.42 & $94.53 \pm 15.14$ \\
Actinomycete SCA54.P2 & 156.96 & 102.72 & 133.98 & $131.22 \pm 22.23$ \\
\hline
\end{tabular}

Table 3. The antimicrobial activities of actinomycete HV11.P3 and SCA54.P2 pigment extracts (750 $\mu \mathrm{g} / \mathrm{mL})$ against several tested microbes

\begin{tabular}{cccccc}
\hline & \multicolumn{3}{c}{ Tested microbes } \\
\cline { 2 - 6 } Pigment extract & $\begin{array}{c}\text { Bacillus subtilis } \\
\text { ATCC 19659 }\end{array}$ & $\begin{array}{c}\text { Escherichia coli } \\
\text { ATCC 8739 }\end{array}$ & $\begin{array}{c}\text { Pseudomonas } \\
\text { aeruginosa } \\
\text { ATCC 15442 }\end{array}$ & $\begin{array}{c}\text { Staphylococcus } \\
\text { aureus } \\
\text { ATCC 6538 }\end{array}$ & $\begin{array}{c}\text { Candida } \\
\text { albicans } \\
\text { ATCC 10231 }\end{array}$ \\
\hline Actinomycete HV11.P3 & + & + & - & + & - \\
Actinomycete SCA54.P2 & + & ++ & + & - & - \\
\hline
\end{tabular}

Note: 0.1-5 mm (+), 6-10 mm (++), and 11-15 (+++)

Table 4. The antioxidant activities of actinomycete HV11.P3 and SCA54.P2 pigment extracts against DPPH as free radical

\begin{tabular}{lcccc}
\hline \multirow{2}{*}{ Pigment extract } & \multicolumn{4}{c}{ IC $_{\mathbf{5 0}}$ value $(\boldsymbol{\mu g}$ / $\mathbf{~ m L})$} \\
\cline { 2 - 5 } & Replication 1 & Replication 2 & Replication 3 & Average \\
\hline Actinomycete HV11.P3 & 243.40 & 224.07 & 225.78 & $231.08 \pm 8.74$ \\
Actinomycete SCA54.P2 & 436.77 & 373.95 & 297.18 & $369.3 \pm 57.08$ \\
\hline
\end{tabular}

\section{Antimicrobial activities of pigment extracts}

The pigment extracts of actinomycetes were tested against both Gram-positive and Gram-negative bacteria, as well as yeast. Based on the antimicrobial test, the pigment extract of actinomycete HV11.P3 and SCA54.P2, exhibited antimicrobial activity against several tested microbes. The HV11.P3 pigment extract possessed positive activities against B. subtilis, E. coli, and $S$. aureus. On the other hand, SCA54.P2 pigment extract could inhibit B. subtilis, E. coli, and $P$. aeruginosa activity (Table 3 ). No inhibition zone was observed for both of those extracts against $C$. albicans.

\section{Antioxidant activities of pigment extracts}

Both of the pigment extracts derived from actinomycete HV11.P3 and SCA54.P2 showed scavenging activity against DPPH as free radical. Actinomycete HV11.P3 and SCA54.P2 pigment extracts exhibited an $\mathrm{IC}_{50}$ value of $231.08 \mu \mathrm{g} / \mathrm{mL}$ and $369.30 \mu \mathrm{g} / \mathrm{mL}$, respectively (Table 4). $\mathrm{IC}_{50}$ is a standard value for the lowest concentration that can inhibit $50 \%$ activity of free radicals.

\section{Chemical compound identification}

Gas Chromatography-Mass Spectrometry (GC-MS) analysis was used for investigating the dominant extract compound. The dominant compound in actinomycete HV11.P3 pigment extract was 1H-Purine-2,6-dione,3,7-dihydro1,3,7-trimethyl- (Figure 2; Table 5), while for actinomycete SCA54.P2 pigment extract the dominant compound was 5Methoxypyrrolidin-2-one (Figure 3; Table 6).

\section{Molecular identification}

Amplification of 16S rRNA genes from actinomycete HV11.P3 and SCA54.P2 genome showed 1480 bp band after visualization by gel electrophoresis (Figure 4). Based on analysis of $16 \mathrm{~S}$ rRNA gene sequences of the two actinomycetes exhibited the same closest similarity with Micromonospora genera (Table 7). The constructed phylogenetic tree of the two 16S rRNA sequences of the two actinomycetes showed their position among other actinomycetes. Actinomycete HV11.P3 showed the closest similarity with Micromonospora chalcea strain 1464-217L, while actinomycete SCA54.P2 showed the closest similarity with Micromonospora tulbaghiae strain TVU1 (Figure 5). 


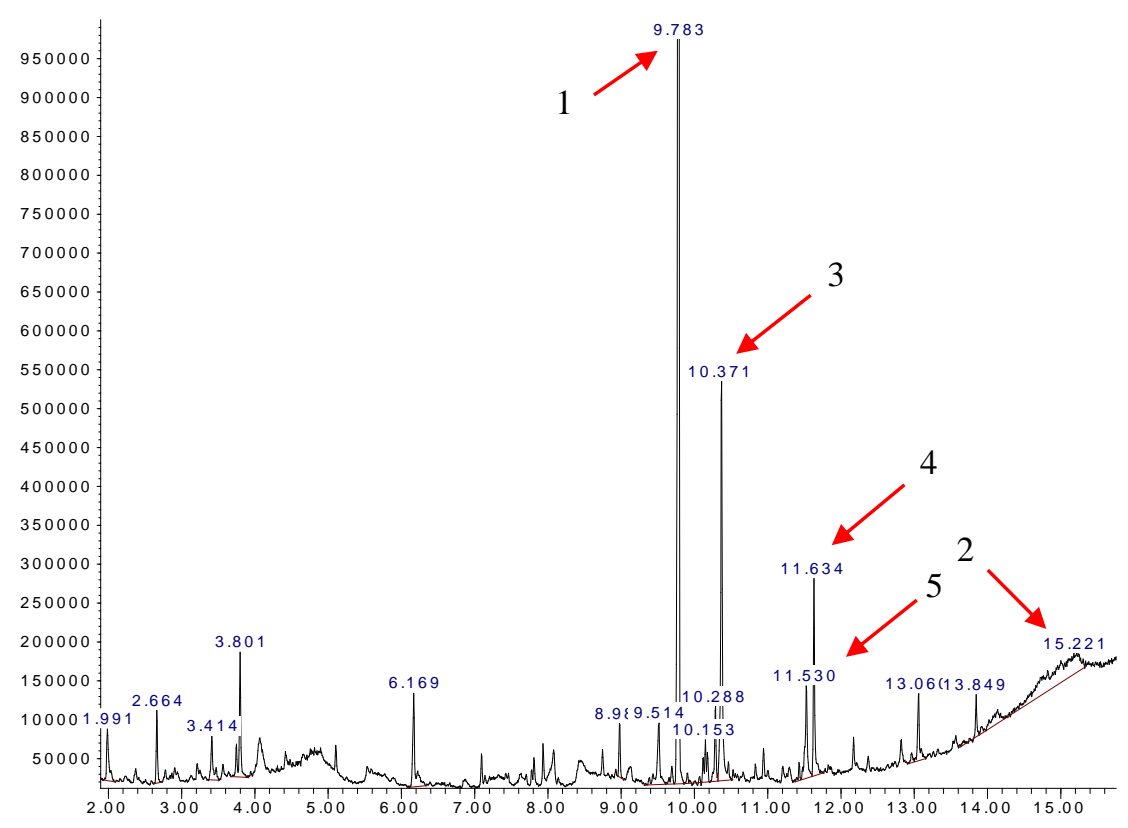

Figure 2. Chromatogram of chemical compounds of pigment extract derived from actinomycete HV11.P3 based on GC-MS analysis showing five dominant compounds as indicated by red arrows

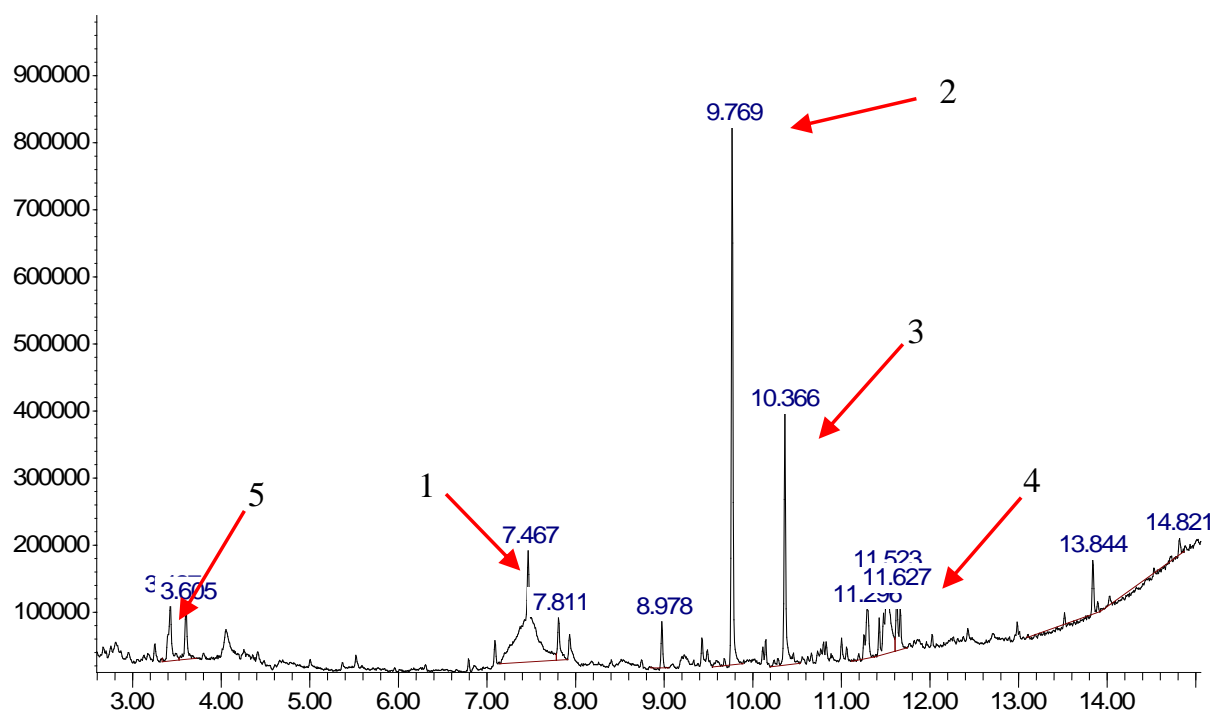

Figure 3. Chromatogram of chemical compounds of pigment extract derived from actinomycete SCA54.P2 based on GC-MS analysis showing five dominant compounds as indicated by red arrows

Table 5. Five major chemical compounds of actinomycete HV11.P3 pigment extract and their biological activities.

\begin{tabular}{lcll}
\hline \multicolumn{1}{c}{ Chemical compound } & $\begin{array}{c}\text { Peak area } \\
\mathbf{( \% )}\end{array}$ & \multicolumn{1}{c}{ Activity } & Reference \\
\hline 1H-Purine-2,6-dione, 3,7-dihydro-1,3,7-trimethyl- (CAS) & 44.65 & Anti-inflammation & Rezaei et al. (2021) \\
$\begin{array}{l}\text { Cyclotrisiloxane, hexamethyl- (CAS) } \\
\text { n-Hexadecanoic acid (CAS) }\end{array}$ & 13.20 & $\begin{array}{l}\text { Antimicrobial } \\
\text { Antibacterial, antioxidant, } \\
\text { toxic compound }\end{array}$ & Keskin et al. (2012) \\
Octadecanoic acid (CAS) & 11.10 & Antibacteni et al. (2014) \\
9-Octadecenoic acid & 4.46 & Antial, & Pradheesh et al. (2017) \\
\hline
\end{tabular}


Table 6. Five major chemical compounds of actinomycete SCA54.P2 pigment extract and their biological activities.

\begin{tabular}{lcll}
\hline \multicolumn{1}{c}{ Chemical compound } & $\begin{array}{c}\text { Peak area } \\
(\boldsymbol{\%})\end{array}$ & \multicolumn{1}{c}{ Activity } & \multicolumn{1}{c}{ Reference } \\
\hline 5-Methoxypyrrolidin-2-one & 30.23 & Antioxidant & Dascalu et al. (2020) \\
1H-Purine-2,6-dione, 3,7-dihydro-1,3,7-trimethyl- (CAS) & 24.27 & Anti-inflammation & Rezaei et al. (2021) \\
n-Hexadecanoic acid & 12.93 & Antibacterial & Krishnaveni et al. (2014) \\
9,12,15-Octadecadienoic acid (Z,Z,Z)- & 12.26 & Antibacterial & Ojinnaka et al. (2015) \\
4H-Pyran-4-one, 2-hydroxy-3-methyl-(CAS) & 5.05 & Anti-proliferative, antioxidant & Amatori et al. 2010 \\
\hline
\end{tabular}

Table 7. Molecular identification of the actinomycetes isolates based on the 16S rRNA gene

\begin{tabular}{|c|c|c|c|c|c|}
\hline Isolate & Closest relative & $\begin{array}{c}\text { Query cover } \\
(\%)\end{array}$ & E-Value & $\begin{array}{c}\text { Percent } \\
\text { identification }(\%)\end{array}$ & $\begin{array}{l}\text { Accession } \\
\text { Number }\end{array}$ \\
\hline Actinomycete HV11.P3 & $\begin{array}{l}\text { Micromonospora chalcea } \\
\text { strain 1464-217L }\end{array}$ & 99 & 0.0 & 97.9 & NR_036795.1 \\
\hline Actinomycete SCA54.P2 & $\begin{array}{l}\text { Micromonospora tulbaghiae } \\
\text { strain TVU1 }\end{array}$ & 100 & 0.0 & 100 & NR_116241.1 \\
\hline
\end{tabular}

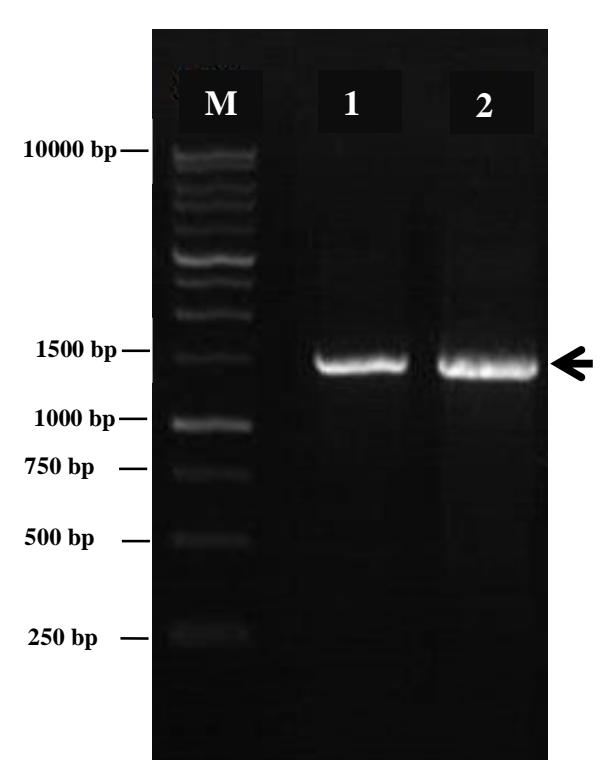

Figure 4. Gel electrophoresis of 16S rRNA genes amplified from actinomycete genomes. 1: actinomycete HV11.P3; 2: actinomycete SCA54.P2; M: Marker $1 \mathrm{~Kb}$ ladder

\section{Discussion}

In our study, HV11.P3 and SCA54.P2 were found to be capable of producing intracellular pigments that were greenish-black and orange, respectively. Based on the BSLT test, pigment extract of HV11.P3 and SCA54.P2 showed a high in vivo toxicity effect with an $\mathrm{LC}_{50}$ value of less than $150 \mu \mathrm{g} / \mathrm{mL}$. BSLT test was used as preliminary test to search for an anticancer agent (Elsyana et al. 2016). Therefore, further study to evaluate the cytotoxic activity against human cells need to be done. Promising antimicrobial abilities will lead to great activity of toxicity (Pandit et al. 2018). Some compound such as antimicrobial peptide (AMP) has been found to have dual action as antimicrobial as well as cytotoxic activity (Felicio et al. 2017). Actinomycete SCA54.P2 and HV11.P3 pigment crude extracts showed a low to moderate activity against the tested bacteria. Both of the extracts could inhibit the
Gram-positive and Gram-negative of the tested bacteria. However, none of these extracts had activity against $C$. albicans as a representative of the eukaryotic cell. Pigments derived from actinomycetes have been gaining much attention due to their therapeutic potencies, one of them is antimicrobial activities (Mumtaz et al. 2018).

In order to investigate their antioxidant activity, both of our pigment extracts were tested for their in vitro antioxidant activities. Our results revealed that actinomycete HV11.P3 and SCA54.P2 pigment extracts had $\mathrm{IC}_{50}$ value of $23.08 \mu \mathrm{g} / \mathrm{mL}$ and $369.30 \mu \mathrm{g} / \mathrm{mL}$ against DPPH radicals, respectively. The antioxidant may decrease the oxidative stress level on the cell. The low level of free radical is undoubtedly reduced the possibility of cell damage and antibiotics effectivity. However, some antioxidant agents were reported to have potent antibacterial activity. The mechanisms involved in this process have been described previously (Naqvi et al. 2019; Dwyer et al. 2014). Interestingly, both our crude extracts also showed antioxidant and antibacterial activity. Our findings were consistent with research done using Streptomyces sp. VITSTK7 that possessed both antibacterial and antioxidant activities (Thenmozhi and Kannabiran 2012).

Furthermore, to understand the possible chemical compounds involved in their biological activities, we identified the chemical composition of the pigment extracts by GC-MS analysis. Some of those compounds include benzene, alcohols, esters, fatty acids, and amino acids groups. The presences of n-Hexadecanoic acid (CAS), Octadecanoic acid (CAS), and 9,12,15-Octadecadienoic acid $(Z, Z, Z)$ in our present study may be the main compounds that play a role in inhibiting microbial growth. Our results are in line with the previous study that revealed these compounds can inhibit the growth of bacteria such as E. coli (Gram-negative bacteria), S. aureus (Gram-positive bacteria), and the fungus Aspergillus flavus (Krishnaveni et al. 2014). Meanwhile, n-Hexadecanoic acid (CAS) may also play a significant role along with 5Methoxypyrrolidin-2-one which may act as an antioxidant agent (Dascalu et al. 2020). 


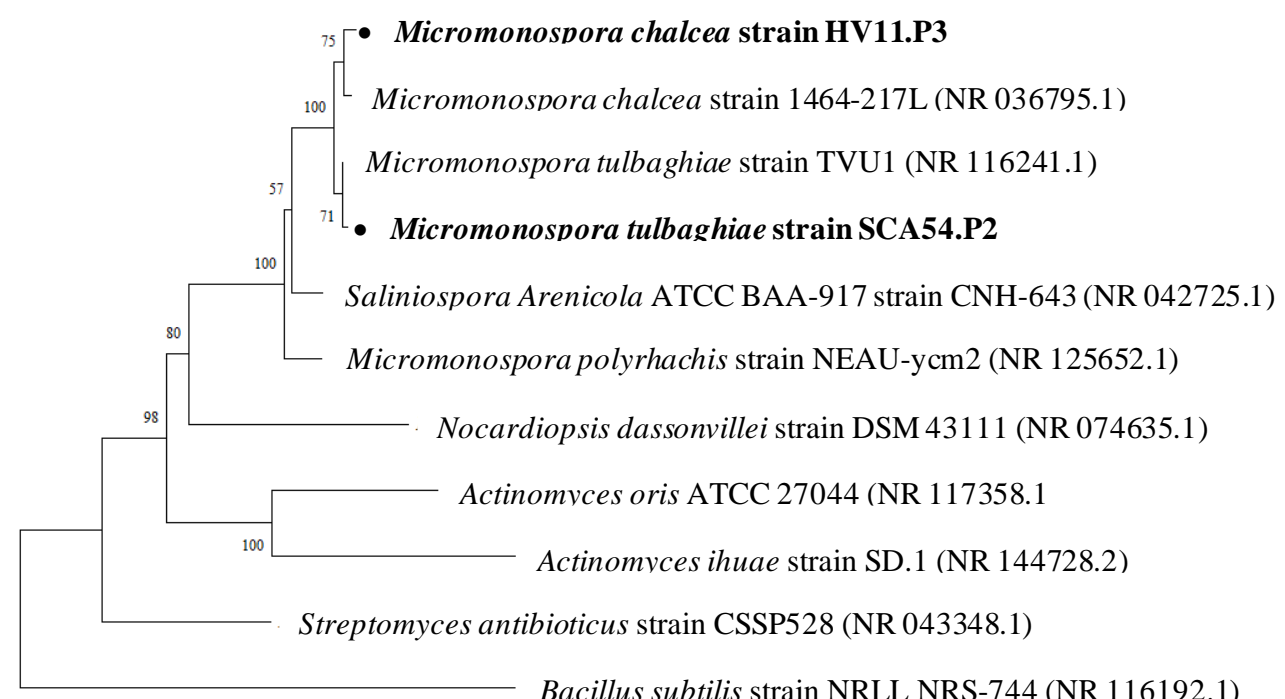

Bacillus subtilis strain NRLL NRS-744 (NR 116192.1)

Figure 5. Neighbor-joining phylogenetic tree of the 16S rRNA gene sequence of actinomycete HV11.P3 and SCA54.P2 on bootstrap values 1000x. Both actinomycetes showed the closest similarity with the genus of Micromonospora.

Identification of the two actinomycete isolates was performed based on the 16S rRNA gene sequence. As a result, both actinomycetes belong to the genus Micromonospora. The actinomycete HV11.P3 showed a similarity percentage of $97.9 \%$ with Micromonospora chalcea strain 1464-217L, and actinomycete SCA54.P2 showed a $100 \%$ similarity percentage with Micromonospora tulbaghiae strain TVU1. The genus Micromonospora is known to be able to produce various types of bioactive compounds such as oligosaccharides, terpenes, and lanthipeptides that have therapeutic activity as antibacterial (Back et al. 2021), antitumor and antioxidant (Nafie et al. 2021), antifungal (Zhao et al. 2017), and antivirus (Debbab et al. 2010).

Thus, the present results revealed that methanol extract of pigments derived from two actinomycetes identified as Micromonospora chalcea HV11.P3 and Micromonospora tulbaghiae SCA54.P2 showed antibacterial, antioxidant, and toxicity activities. The best antibacterial activity of the pigment extract was shown by M. tulbaghiae SCA54.P2 against $E$. coli ATCC 8739, while the M. chalcea HV11.P3 pigment extract showed the best activity as an antioxidant.

\section{ACKNOWLEDGMENTS}

This work was financially supported by the Basic Research ("Penelitian Dasar") from the Ministry of Research and Technology/ National Research and Innovation Agency of the Republic of Indonesia (Contract No: $1 / \mathrm{E} 1 / \mathrm{KP} . P T N B H / 2021)$ to ATW. The authors thank for all the support to complete this work.

\section{REFERENCES}

Al-Snafi AE. 2017. Medicinal plants possessed antioxidant and free radical scavenging effects (part 3)-a review. IOSR J Pharm 7: 48-62. DOI: $10.9790 / 3013-0704014862$

Amatori S, Bagaloni I, Macedi E, Formica M, Giorgi L, Fusi V, Fanelli M. 2010. Malten, a new synthetic molecule showing in vitro antiproliferative activity against tumour cells and induction of complex DNA structural alterations. Br J Cancer 103: 239-248. DOI: 10.1038/sj.bjc. 6605745

Back CR, Stennett HL, Williams SE, Wang L, Ojeda Gomez J, Abdulle OM, Duffy T, Neal C, Mantell J, Jepson MA, Hendry KR. 2021. A new Micromonospora strain with antibiotic activity isolated from the microbiome of a mid-Atlantic deep-sea sponge. Mar Drugs 19: 1-19. DOI: $10.3390 / \mathrm{md} 19020105$

Batubara I, Mitsunaga T, Ohashi H. 2009. Screening antiacne potency of Indonesian medicinal plants: antibacterial, lipase inhibition, and antioxidant activities. J Wood Sci 55: 230-235. DOI: 10.1007/s10086008-1021-1

Bérdy J. 2005. Bioactive microbial metabolites. J Antibiot 58: 1-26. DOI: 10.1038/ja.2005.1

Bhakyashree K, Kannabiran K. 2018. Anti-MRSA activity of actinomycetes isolated from marine soil sample of ariyaman beach, Tamil Nadu, India. Res J Pharm Technol 11: 2036-2039. DOI: 10.5958/0974-360X.2018.00377.3

Bibi F, Yasir M, Al-Sofyani A, Naseer MI, Azhar EI. 2020. Antimicrobial activity of bacteria from marine sponge Suberea mollis and bioactive metabolites of Vibrio sp. EA348. Saudi J Biol Sci 27: 1139-1147. DOI: $10.1016 /$ j.sjbs.2020.02.002

Dascalu AE, Ghinet A, Lipka E, Furman C, Rigo B, Fayeulle A, Billamboz M. 2020. Design, synthesis and evaluation of hydrazine and acyl hydrazone derivatives of 5-pyrrolidin-2-one as antifungal agents. Bioorg Med Chem Lett 30: 1-6. DOI: 10.1016/j.bmcl.2020.127220

Dawoud TM, Alharbi NS, Theruvinthalakal AM, Thekkangil A, Kadaikunnan S, Khaled JM, Almanaa TN, Sankar K, Innasimuthu GM, Alanzi KF, Rajaram SK. 2020. Characterization and antifungal activity of the yellow pigment produced by a Bacillus sp. DBS4 isolated from the lichen Dirinaria agealita. Saudi J Biol Sci 27: 14031411. DOI: $10.1016 /$ j.sjbs.2019.11.031 
Debbab A, Aly AH, Lin WH, Proksch P. 2010. Bioactive compounds from marine bacteria and fungi. Microb Biotechnol 3: 544-563. DOI: 10.1111/j.1751-7915.2010.00179.x

Dwyer DJ, Belenky PA, Yang JH, MacDonald IC, Martell JD, Takahashi N, Chan CT, Lobritz MA, Braff D, Schwarz EG, Jonathan DY. 2014 Antibiotics induce redox-related physiological alterations as part of their lethality. Proc Natl Acad Sci USA 111: 100-109.

Elsyana V, Bintang M, Priosoeryanto BP. 2016. Cytotoxicity and antiproliferative activity assay of clove mistletoe (Dendrophthoe pentandra (L.) Miq.) leaves extracts. Adv Pharmacol Pharm Sci 2016 1-6. DOI: $10.1155 / 2016 / 3242698$

Felício MR, Silva ON, Gonçalves S, Santos NC, Franco OL. 2017 Peptides with dual antimicrobial and anticancer activities. Front Chem 5: 1-9. DOI: 10.3389/fchem.2017.00005

Founou RC, Founou LL, Essack SY. 2017. Clinical and economic impact of antibiotic resistance in developing countries: a systematic review and meta-analysis. PLoS One 12: 1-18. DOI: 10.1371/journal.pone.0189621

Genilloud O. 2015. Micromonospora. BMSAB 1-28. DOI: 10.1002/9781118960608.gbm00148

Gong B, Chen S, Lan W, Huang Y, Zhu X. 2018. Antibacterial and antitumor potential of actinomycetes isolated from mangrove soil in the Maowei Sea of the Southern Coast of China. Iran J Pharm Res 17: 1339-1346.

Hifnawy SM, Hassan HM, Mohammed R, M Fouda M, Sayed AM, A Hamed A, F AbouZid S, Rateb ME, Alhadrami HA, Abdelmohsen UR. 2020. Induction of antibacterial metabolites by co-cultivation of two red-sea-sponge-associated actinomycetes Micromonospora sp. UR56 and Actinokinespora sp. EG49. Mar drugs 18:243. DOI: 10.3390/md18050243

Kapoor G, Pathak DP, Bhutani R, Husain A, Jain S, Iqbal MA. 2019 Synthesis, ADME, docking studies and in vivo anti-hyperglycaemic potential estimation of novel Schiff base derivatives from octadec-9. enoic acid. Bioorg Chem 84: 478-492. DOI: 10.1016/j.bioorg.2018.12.004

Keskın D, Ceyhan N, Uğur A, Dbeys AD. 2012. Antimicrobial activity and chemical constitutions of West Anatolian olive (Olea europaea L.) leaves. J Food Agric Environ 10: 99-102.

Kharirie K, Andriani L. 2020. The predominance of non-communicable diseases and unhealthy eating patterns. In: Proceeding of National Seminar of Indonesia Biodiversity Community. Sebelas Maret University, Bogor, 12 October 2019. [Indonesian]

Krishnaveni M, Nandhini N, Dhanalakshmi R. 2014. GC-MS analysis of phytochemicals, fatty acids and antimicrobial potency of dry christmas lima beans. Int J Pharm Sci Rev Res 27: 63-66.

Liao L, Chen R, Jiang M, Tian X, Liu H, Yu Y, Fan C, Chen B. 2016 Bioprospecting potential of halogenases from Arctic marine actinomycetes. BMC microbiol 16: 1-9. DOI: 10.1186/s12866-0160662-2

McLaughlin JL, Rogers LL, Anderson JE. 1998. The use of biological assays to evaluate botanicals. Drug Inf J 32: 513-524. DOI $10.1177 / 009286159803200223$

Meyer BN, Ferrigni NR, Putnam JE, Jacobsen LB, Nichols DJ, McLaughlin JL. 1982. Brine shrimp: a convenient general bioassay for active plant constituents. Planta Med 45: 31-34. DOI: $10.1055 / \mathrm{s}-$ 2007-971236

Mumtaz R, Bashir S, Numan M, Shinwari ZK, Ali M. 2018. Pigments from soil bacteria and their therapeutic properties: A mini review. Curr Micribiol 76: 783-790. DOI: 10.1007/s00284-018-1557-2
Nafie MS, Awad NM, Tag HM. 2021. Micromonospora species from rarely-exploited Egyptian habitats: chemical profile, antimicrobial, and antitumor activities through antioxidant property. Appl Microbiol Biotechnol 105: 2427-2439. DOI: 10.1007/s00253-021-11177-2

Naqvi SA, Nadeem S, Komal S, Naqvi SA, Mubarik MS, Qureshi SY, Ahmad S, Abbas A, Zahid M, Raza SS, Aslam N. 2019. Antioxidants: Natural Antibiotics. IntechOpen, London.

Ojinnaka, Chukwunonye M, Kelechi IN, Marycolette NE. 2005. The chemical constituents and bioactivity of the seed (Fruit) extracts of Buchholzia Coriacea Engler (Capparaceae). J Appl Sci Environ Manag 19: 795-801. DOI: 10.4314/jasem.v19i4.29

Pandit S, Dhawan A, Parthasarathi R. 2018. Emerging computational methods for predicting chemically induced mutagenicity. Academic Press, London. DOI: 10.1016/B978-0-12-809252-1.00008-0

Pradheesh G, Suresh J, Suresh S, Alexramani V. 2017. Antimicrobial activity and identification of potential ethanolic antimicrobial compounds from the medicinal plant Pisonia grandis r.br. World J Pharm Pharm Sci 6: 1686-1700. DOI: 10.20959/wjpps20174-8961

Prestinaci F, Pezzotti P, Pantosti A. 2015. Antimicrobial resistance: a global multifaceted phenomenon. Pathog Glob Health 109: 309-318. DOI: 10.1179/2047773215Y.0000000030

Pudi N, Varikuti GD, Badana AK, Gavara MM, Singh SK, Malla R. 2016. Studies on optimization of growth parameters for enhanced production of antibiotic alkaloids by isolated marine actinomycetes. J Appl Pharm Sci 6: 181-188. DOI: 10.7324/JAPS.2016.601025

Rezaei H, Rahimpour E, Zhao H, Martinez F, Jouyban A. 2021. Solubility measurement and thermodynamic modeling of caffeine in n-methyl2-pyrrolidone+ isopropanol mixtures at different temperatures. J Mol Liq 363: 116519. DOI: 10.1016/j.molliq.2021.116519

Roope LS, Smith RD, Pouwels KB, Buchanan J, Abel L, Eibich P, Butler CC, San Tan P, Walker AS, Robotham JV, Wordsworth S. 2019. The challenge of antimicrobial resistance: What economics can contribute. Science 364: 1-8. DOI: 10.1126/science.aau4679

Sahardi NFNM, Makpol S. 2019. Ginger (Zingiber officinale Roscoe) in the prevention of ageing and degenerative diseases: review of current evidence. Evid Based Complement Alter Med 2019: 1-13. DOI: 10.1155/2019/5054395

Stambler I. 2017. Recognizing degenerative aging as a treatable medical condition: methodology and policy. Aging Dis 8: 583-589. DOI: 10.14336/AD.2017.0130

Sineva ON, Bychkova OP, Terekhova LP. 2021. Acidotolerant actinomycetes of the genus Micromonospora are producers of antibiotic compounds. In Presented At: The First International Electronic Conference On Antibiotics 8:17.

Thenmozhi M, Kannabiran K. 2012. Antimicrobial and antioxidant properties of marine actinomycetes Streptomyces sp. VITSTK7. Oxid Antioxid Med Sci 1: 51-57. DOI: 10.5455/oams.270412.or.005

Trujillo ME, Riesco R, Benito P, Carro L. 2015. Endophytic actinobacteria and the interaction of Micromonospora and nitrogen fixing plants. Front Microbiol 6: $1341 . \quad$ DOI: 10.3389/fmicb.2015.01341

Weisberg WG, Barns SM, Pelletier DA, Lane DJ. 1991. 16S ribosomal DNA amplification for phylogenetic study. J Bacteriol 173: 697-703. DOI: $10.1128 /$ jb.173.2.697-703.1991

Zhao S, Liu C, Zheng W, Ma Z, Cao T, Zhao J, Yan K, Xiang W, Wang X. 2017. Micromonospora parathelypteridis sp. nov., an endophytic actinomycete with antifungal activity isolated from the root of Parathelypteris beddomei (Bak.) Ching. Int J Syst Evol Microbiol 67: 268-274. DOI: 10.1099/ijsem.0.001614 